
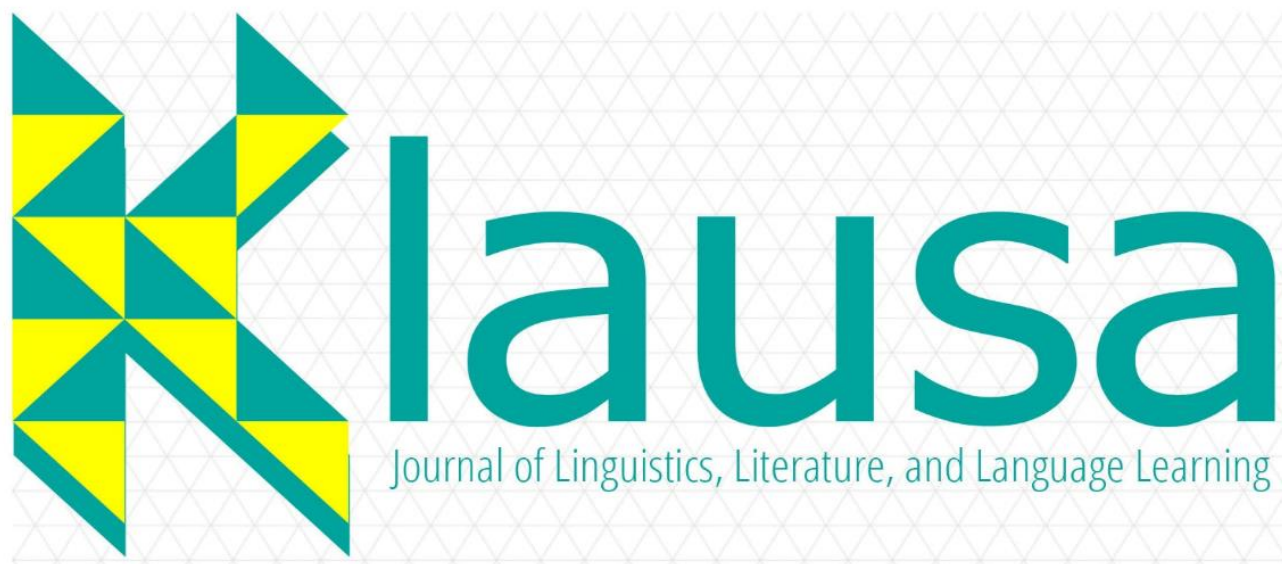

Journal of Linguistics, Literature, and Language Learning

ISSN: $2301-4822(p)$

\section{$\Delta \Delta \| 5 \pi \bigcirc$ Kajian Linguistik, Pembelajaran Bahasa, dan Sastra}

\section{Editorial Team}

\section{Editor-in-Chief}

Journal Manager

Editors

Reviewers

Publisher

Address

Frequency
: Dr. Daniel Ginting

: Wawan Eko Yulianto, Ph.D.

: Prof. Dr. Patrisius I. Djiwandono

Lilis Lestari Wilujeng, M.Hum.

: F.X Dono Sunardi, M.A. Dhatu Sitaresmi, MTCSOL. Anggrah Diah Arlinda, MTCSOL. Yohanna Nirmalasari, S.Pd., M.Pd. Prof. A. Effendi Kadarisman, Ph.D. Sisilia Halim, Ph.D.

Dr. Mundi Rahayu

Dr. Ross Wood

Dr. Leticia Araceli Salas Serrano

: Faculty of Language and Arts

Universitsas Ma Chung

: The Faculty of Language and Arts

Ma Chung University

Villa Puncak Tidar N-01 (65151)

Malang, East Java, Indonesia

Email: jurnal.klausa@machung.ac.id

: Twice a year 


\section{CONTENTS}

FOREWORD

THE STRUCTURE OF COLLOCATION AND ITS TRANSLATION

STRUCTURES IN SUBTITLES OF KURZGESAGT

YOUTUBE CHANNEL

Cynthia Veronika

THE INSEPARABLE NARRATOLOGY AND GENRE IN DISNEY'S ALADDIN (2019): A STRUCTURALIST CRITICISM 11

Sandi Hamim

JUNIOR HIGH SCHOOL PERCEPTION OF COOPERATIVE

GROUP WORK

Puspita Nugraha Wibisono

THE INTEGRATION OF ISLAMIC VALUES IN THE

DEVELOPMENT OF LISTENING COURSE MATERIALS

Mazroatul Ishlahiyah, Mira Shartika

POLA ARGUMEN MAHASISWA JURUSAN PENDIDIKAN BAHASA

MANDARIN

Yohanna Nirmalasari 
ii | DOI: 10.33479/klausa.v4i01 


\title{
JUNIOR HIGH SCHOOL PERCEPTION OF COOPERATIVE GROUP WORK
}

\author{
Puspita Nugraha Wibisono ${ }^{1}$ \\ ${ }^{1}$ Universitas Widya Mandala Surabaya, puspita.wibisono@gmail.com
}

\begin{abstract}
Cooperative learning is not only about studying and sitting together, but it is more about structuring the group work. Structuring group work includes guidance of step by step to do the assignment. In the assessment process of group work, teachers tend to assess students individually, which is disassociated. To bridge the gap, representativeness assessment is introduced as a current insight. This study aimed to identify student's perception toward cooperative group work strategies and representative assessment. In this research, data were collected through questionnaires from a population of students. The result of the study showed that the respondents showed high percentage of perception on both cooperative group work strategies and representative assessment.
\end{abstract}

Key Terms: Cooperative Learning, Group Work, Structured Discussion, Representativeness, Authentic Assessment

\section{INTRODUCTION}

In this modern era, students are actively finding and discussing the information in the teaching learning process which is contrasted with the old approach where students passively receive the knowledge. They learn actively through working with one another in the group. Here, the students are given greater chance and opportunity to talk because they are engaged in the learning process. Several studies have reported that student-centered learning promotes better learning outcomes, greater retention, and more inclusive class environments than does the lecture alone (Freeman et al., 2014; Hake, 1998; Springer, Stanne \& Donovan, 1999 as cited in Hodges, 2017). Simply students are often involved in group work.

The philosophy behind group work is social constructivism, which is developed by Lee Vygotsky. He has the same point of view with Piaget, who believes that children actively construct their knowledge. However, Vygotsky gives social interaction and culture far more important roles in cognitive development rather than Piaget does (Santrock, 2009). For that reason, students who work and have social interaction with more-skilled adults and peers are indispensable to their cognitive development (Holzman, 2009; Tamah, 2017). When students work in group and interact with each other, they indirectly learn to use the tools that will help them to be successful in the future.

Numerous of studies demonstrate that group work interaction engages students in learning concepts and problems solving strategies, improves self-confidence, and overcomes the fear of mistake (Davidson 1985; Kocak et al., 2009; Berneto, 2000 as cited in Sofroniou \& Poutos, 2016). 
Even though group work has several advantages, there are several drawbacks found in the implementation of group work, like dominating, hitchhiking and talking unrelated topics. Therefore, the result of group work application tends to be perceived as negative (Lie, 2002). The failure of accomplishing the task will be remarked by blaming on one another. The success yet will raise fairness issue between high and low achievers.

Those problems might happen because the application of group work does not follow cooperative learning components. As pointed out by Lie (2002) \& Tamah (2017), cooperative learning is not only about learning and sitting together, but more on structuring the group work. Sparks (2017), moreover, convincingly states that collaboration is just like any other skill, so it must be taught. It means teachers cannot expect the students to do the work by themselves without any supervision. The supervision can be applied when teachers intervene and monitor students' interaction in group. Therefore, this study underlies the concept of group work in cooperative learning which is named cooperative group work. Tamah (2017) defined cooperative group work as a very structured group work that enables students to work together optimally and help each other in their academic tasks. The implementation of cooperative group work was adopted from Tamah (2017).

Learning and assessment are inseparable in which they complete one another. One of the literatures also says that assessment is the celebration of learning. Assessment or a test, in plain words, is a method of measuring a person ability or knowledge in a given domain (Brown, 2001). When assessing the result of group work, teachers mostly still assess students individually, either by taking the score of the lowest student or averaging the scores of each team member (Lie, 2002; Tamah \& Prijambodo, 2015 who refer to Tamah \& Prijambodo, 2014). Possible problems that might arise are high achieving students feel disappointed, while low achieving students feel guilty. It might be concluded that there is a disassociation between the application of cooperative group work and the implementation of cooperative group work assessment. Referring to a research report (Tamah \& Prijambodo, 2014; Tamah \& Wirjawan, 2018) and the explicit ideas of representativeness in assessment (Tamah and Prijambodo, 2015; Tamah, 2017), three current insights with regard to assessment-oriented formative test are introduced.

\section{RESEARCH OBJECTIVES}

This paper was designed to find out student's perception about language learning on cooperative group work strategies, such as ice breaker, modelling group work, group naming, and group membersship. In addition, this study also investigated student's perception on representative assessment in cooperative group work.

\section{Cooperative Group Work}

Cooperative learning is the instructional use of small groups so that students work together to maximize their own and each other's learning (Smith, 1996 who refers Johnson, Johnson \& Smith, 1991). Here, students are placed to work together on a common task, sharing information and supporting one another (Tamah, 2007). In a cooperative learning class, teachers design and assign group learning tasks, manage time, and resources, monitor students' learning, check to see 
that students are on task and that group process is working well (Cranton, 1996; Smith, 1996 as cited in Barkley, Cross \& Major, 2005).

Five basic components to consider when applying group work based on cooperative learning is mentioned in numerous articles repeatedly (Felder \& Brent, 2007; Johnson\& Johnson 1994; Kagan \& Kagan, 1994 as cited in Tamah, 2011, 2013, 2014). They are (1) Face to Face interaction, (2) Collaborative Skills, (3) Group Processing, (4) Individual Accountability and (5) Positive Interdependence.

Arranging students' seat does not guarantee that students will work together in group. As pointed out by Lie (2002) \& Tamah (2017), cooperative learning is not only about learning and sitting together, but actually more on structuring the group work. Therefore, Tamah (2017) suggests the combination term of group work and cooperative learning that is cooperative group work. Cooperative group work is a very structured group work that enables students to work together optimally and help each other in their academic tasks. Structuring group work will include guidance of step by step to do the assignment. When students are given guidance, the students might be more structured on finishing the task.

\section{The Implementation of Cooperative Group Work}

The implementation of cooperative group work is adopted from Tamah (2017). There are seven strategies mentioned in the book; however, only four strategies that is discussed further. They are ice breaker, modeling of group work, group naming and role of group members.

\section{Strategy 1: Ice Breaker}

When students firstly enter new school year at the seventh grade or the tenth grade in the beginning of academic year, they are most likely composed of students who do not know each other well. An initial activity that can be used as an introduction for group members who have not known each other is called ice breaker. The aim is to bring cohesion out so that group goals are achieved as expected. If group members feel comfortable with each other, they will willingly participate and come up with new ideas.

\section{Strategy 2: Modelling Group Work}

Cooperative learning will not come up naturally when students are enrolled in small groups. What often happens is that students in groups prefer to do their own tasks. After they finish doing it, they use their friends' answer to check their own answer (Shadle, 2010). It seems that situation happens frequently, therefore it is necessary to conduct group work simulation, although only allocated for one or two times.

By giving model, two components of cooperative learning is indirectly applied: Face to face interaction and Collaborative skills (good interpersonal skills in communicating) is reinforced. Students are indirectly reminded of the need for interaction among students in a group to help one another as well as the need for proper use of interpersonal skills in group work. 
The design of the class is made different from the usual when doing simulation. The design of modelling class is named "Fish bowl Class" This activity is aimed to provide training that simulates a group work activity.

This simulation needs to be pursued because training students for cooperation should not be ignored (Cohen, 1994). Students need special skills while doing the learning process or when engaging in group work to accomplish the tasks assigned to them. This skill is not innate and does not just appear, so it should be taught.

\section{Strategy 3: The Importance of Group Naming}

Education does not only deal with the intellectual knowledge only but also related with norm and moral value. Group naming can help slightly to remind and implicitly put the values of national character or norms of life prevailing in society.

\section{Strategy 4: The Role of Group Members}

One of the characteristics of cooperative group is the necessity for each member to get his/her own role. This feeling is what is meant by positive interdependence. This interdependence can be conditioned on the role assigned to each member so that the task can be shared, and each student plays its part in the group. There are a variety of names used to describe the roles of group members. In this study, we appointed a secretary, a timekeeper, and a speaker.

The secretary is responsible for taking notes on important points and assisting leaders when leaders are stuck in managing the discussion process. The timekeeper manages the time for discussion so that it will be in time with the given time allocation. Meanwhile, the speaker reports the results of the discussion by using notes from the secretary

\section{Assessment in Cooperative Group Work}

Assessing students individually is mostly used by the teacher to assess the result of group work. That is done by taking the score of the lowest student or averaging the scores of each team member (Lie, 2002; Tamah \& Prijambodo, 2015 who refers to Tamah \& Prijambodo, 2014).

It might be concluded that there is a disassociation between the application of cooperative group work and the implementation of cooperative group work assessment. Referring to a research report (Tamah \& Prijambodo, 2014; Tamah \& Wirjawan, 2018) and the explicit ideas of representativeness in assessment (Tamah and Prijambodo, 2015; Tamah, 2017), three current insights with regard to assessment-oriented formative test are introduced. First, the change from individual (conventional) assessment into group assessment. Second, the change from individual (conventional) assessment into representative assessment, and the third articulates the change from individual (conventional) assessment into representative assessment with structured discussion (Tamah \& Prijambodo, 2015; Tamah \& Wirjawan, 2018).

A central feature of three insights of assessment-oriented formative test is the presence of a representative system and the presence of structured discussion. With the representative system, it means not all group members were tested, only two of the four students would represent the group and the scores of these two representatives would be averaged and used for all group 
members. Meanwhile, the use of structured discussion means that there are stages of structured discussion on the implementation of the test.

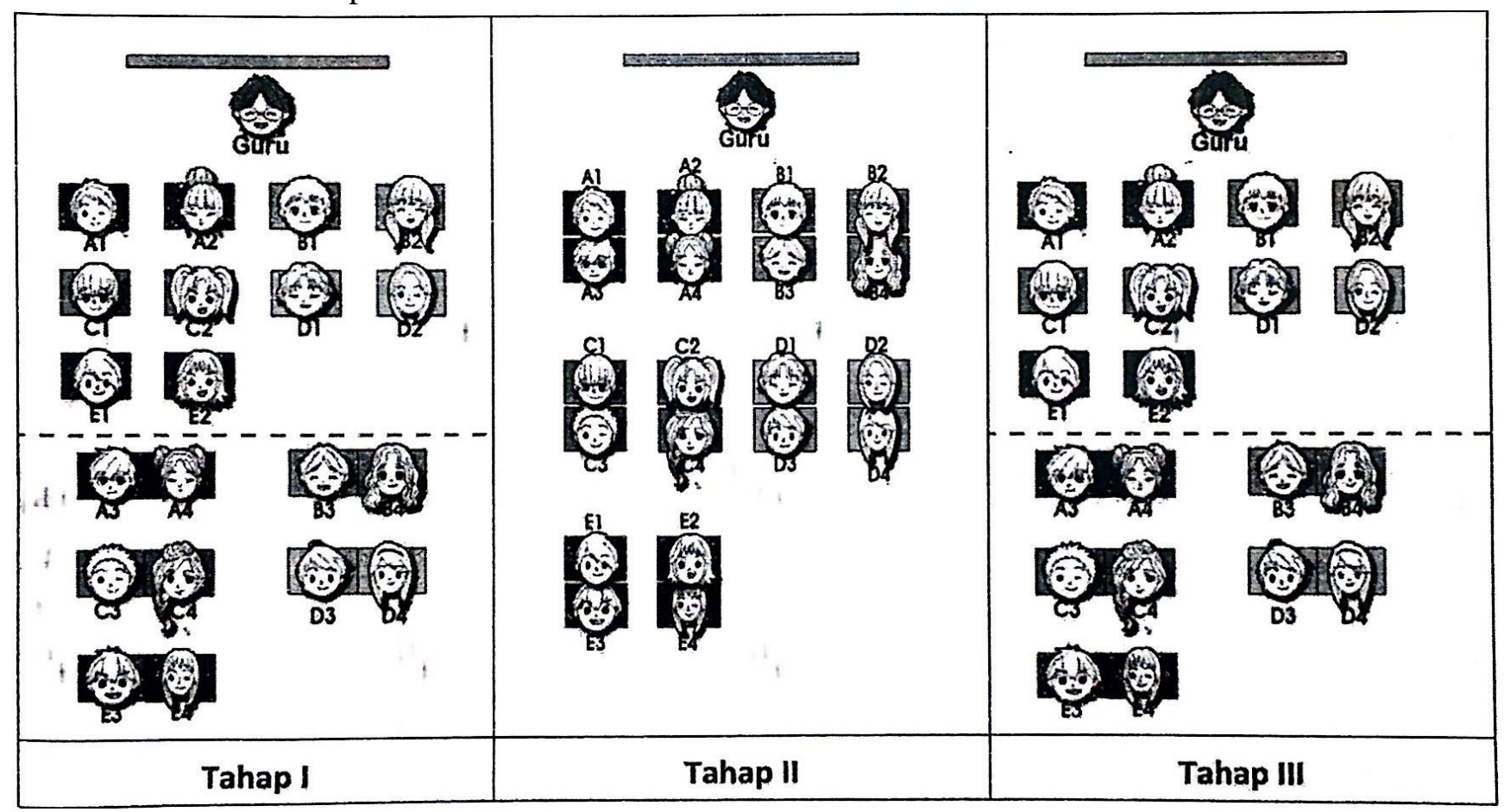

Illustration 1: The Steps of Assessment-Oriented Formative Test

Source: (Tamah, 2017, p. 76 )

\section{RESEARCH METHOD}

This study, which focused on finding out students' perception on cooperative group work, was a descriptive research. The students who had been given treatment on cooperative group work were asked to answer some questions in questionnaire. This study was also categorized as survey research since the data were collected through questionnaire to describe opinion of a group (Fraenkel and Wallen, 2007 as quoted by Pramastiwi, 2014).

This study analyzed the data by making a percentage of each item in the questionnaire based on the response of the participants. The data which had been already collected was presented in the form of table containing percentages and students' responses. The data gathered from the open-ended section were also used to get more information about why a certain answer was chosen.

\section{FINDINGS AND DISCUSSION}

Ice breaker, an initial activity that can be used as an introduction for group members who have not known each other. Students were asked several statements about this activity; usefulness, necessity, influence and frequency, which is summarized in table 1.

In Table 1, only one (4\%) student disagreed with the usefulness of ice breaker. Twentyseven (96\%) students agreed with the statement. One student (S19) gave further opinion about the usefulness of ice breaker: Karena kita perlu berkenalan (translation: Because we need to know 
each other). From the data, it shows that the students realized ice breaker as an important strategy to familiarize students who do not know each other well.

With regard to the necessity of ice breaker, it is seen from Table 1 below that initially the majority of the students (96\%) agreed with the statement. Twenty-seven students agreed with it. It means most of the students understood that this strategy was useful as an introduction for group members. Only one (4\%) student who thought ice breaker was not necessary.

If group members feel comfortable with each other, they will willingly participate and come up with new ideas. Therefore, the students were asked whether ice breaker makes them feel comfortable to work with each other. The result in Table 1 shows high agreement from the students, $89 \%$ strongly agreed with the influence of ice breaker. The students felt that ice breaker makes them involved in the groups work.

Table 1. Perception on Ice Breaker Strategy

\begin{tabular}{|c|c|c|c|c|c|c|c|c|}
\hline \multirow{2}{*}{} & \multicolumn{2}{|c|}{ Usefulness } & \multicolumn{2}{c|}{ Necessity } & \multicolumn{2}{c|}{ Influence } & \multicolumn{2}{c|}{ Frequency } \\
\cline { 2 - 9 } & $\Sigma$ & $\%$ & $\sum$ & $\%$ & $\sum$ & $\%$ & $\sum$ & $\%$ \\
\hline Agree & 27 & $96 \%$ & 27 & $96 \%$ & 25 & $89 \%$ & 17 & $61 \%$ \\
\hline Total & 28 & $100 \%$ & 28 & $100 \%$ & 28 & $100 \%$ & 28 & $100 \%$ \\
\hline
\end{tabular}

To identify the perception on the frequency of the implementation of ice breaker strategy, the students were asked to respond to an item in the questionnaire stating, "Ice breaker is sufficiently done once in a year". The students' answers are presented in Table 1 above. The data indicate that the more than half of the population $(61 \%)$ agreed that ice breaker should be done once in a year. While only 11 students (39\%) thought that this strategy should be done more often.

Simply asking students to work in groups does not make them survive in working together. Modelling group work is suggested as the second strategy to give students picture of ideal group work. As seen on usefulness in Table 2, 89\% students agreed that modelling group work was useful. Only $11 \%$ students disagreed with the usefulness of modelling.

Table 2. Perception on Modelling Group Work Strategy

\begin{tabular}{|c|c|c|c|c|c|c|c|c|}
\hline & \multicolumn{2}{|c|}{ Usefulness } & \multicolumn{2}{|c|}{ Necessity } & \multicolumn{2}{|c|}{ Influence } & \multicolumn{2}{|c|}{ Frequency } \\
\hline & $\sum$ & $\%$ & $\sum$ & $\%$ & $\sum$ & $\%$ & $\sum$ & $\%$ \\
\hline Agree & 25 & $89 \%$ & 27 & $96 \%$ & 22 & $79 \%$ & 14 & $50 \%$ \\
\hline Total & 28 & $100 \%$ & 28 & $100 \%$ & 28 & $100 \%$ & 28 & $100 \%$ \\
\hline
\end{tabular}

It is seen in Table 2, twenty-seven (96\%) students strongly agreed that modelling group was needed. They might realize the strategy gave them model to work in group. On the other hand, small population (4\%) disagreed with the necessity of modelling. One of the students (SS11) gave explanation setiap anggota kelompok sudah punya tanggung jawab masing-masing tanpa harus dilakukan simulasi (translation: Each group member has their own responsibilities without doing simulation). 
It can be argued that seeing without practicing is useless. Therefore, to identify students' engagement, the students were asked to respond to an item in the questionnaire stating, "Modelling group work makes them interact better in group work". Students' answers are presented above in Table 2 . The data indicate that $79 \%$ students strongly agreed to the statement. Only $21 \%$ students disagreed that modelling helping them to work with each other.

To identify the perception on the frequency of the implementation of modelling strategy, the students were asked to respond to an item in the questionnaire whether modelling is sufficiently done once in a year. The data in Table 2 show that 50\% (14 students) thought the strategy should be done more than one. They might need more repetition in order to make them realize their role in the group. Interestingly, 50\% (14 students) agreed that modelling should be done once a year. It means that the result was balanced.

Table 3. Perception on Group Naming Strategy

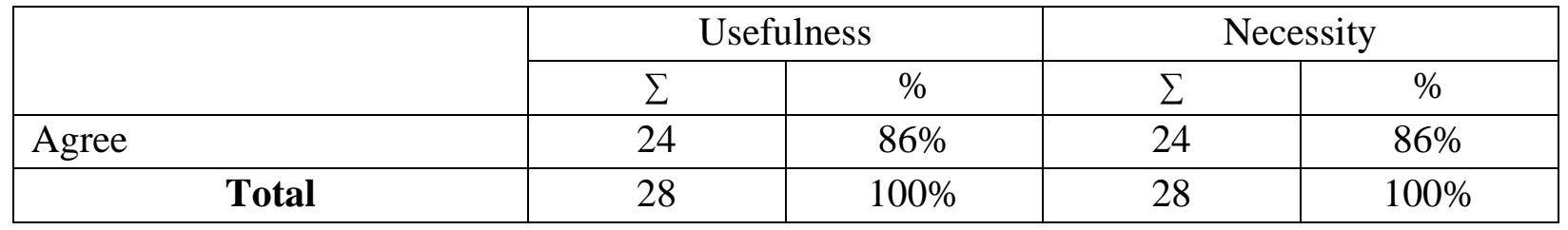

A good group naming can be described as the identity of a group. To identify students' perception on the usefulness of group naming, they were asked to respond to an item in the questionnaire. As can be seen in Table 3 above, $86 \%$ strongly agree that group naming was useful. In contrast, only $14 \%$ disagreed with the statement.

Furthermore, students were asked whether group naming is necessary. The result of data analysis presented in Table 3 indicate that only small population, four (14\%) students who thought group naming was not necessary to be applied. While most students (86\%) strongly agreed with the necessity of group naming.

One of the characteristics of cooperative group is the necessity for each member to get his/her own role. The necessity among group members can be conditioned by assigning role to each member. The purpose is to share task and each student plays its part in the group. The students were asked whether giving roles to group members is useful. Table 4 below reflects that most of the students agreed that role of group members is useful (86\% strongly agreed). Only four (14\%) students who disagreed with the usefulness of group members.

Table 4. Perception on Role of Group Members Strategy

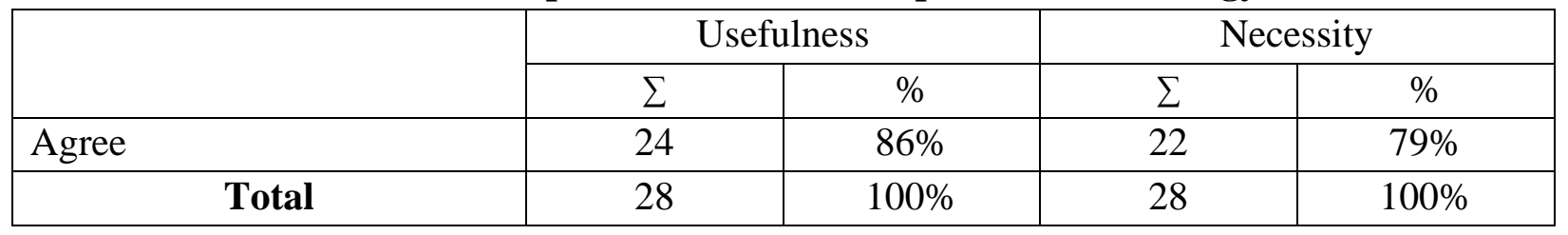

Apparently, students not only agreed that role of group members is useful, but they also thought that role of group members are necessary. As can be seen in Table 4, twenty-seven students 
(79\%) voted that role of group members was necessary. Only six $(21 \%)$ students disagreed with the necessity of role of group members. Therefore, the students might be recognized that giving roles for each member give them clear task to contribute.

The summary for all items related to representativeness assessment is presented in Table 5. The result reflects that most respondents admit that representativeness quiz is useful. Twentyfour $(50 \%)$ students strongly agreed with the statement. While, four (14\%) student disagreed with the statement. It means only small population who was not comfortable with the usefulness of representative quiz.

With regard to the necessity of the new insights of formative test which is assessmentoriented, it is seen from Table 5 that initially the majority of the students $(82 \%)$ thought that the new insights were necessary.

Table 5. Perception on Representative Assessment

\begin{tabular}{|c|c|c|c|c|c|c|c|c|}
\hline \multirow{2}{*}{} & \multicolumn{2}{|c|}{ Usefulness } & \multicolumn{2}{c|}{ Necessity } & \multicolumn{2}{c|}{ Preference } & \multicolumn{2}{c|}{ Relevance } \\
\cline { 2 - 9 } & $\sum$ & $\%$ & $\sum$ & $\%$ & $\sum$ & $\%$ & $\sum$ & $\%$ \\
\hline Agree & 24 & $86 \%$ & 23 & $82 \%$ & 25 & $89 \%$ & 26 & $93 \%$ \\
\hline Total & 28 & $100 \%$ & 28 & $100 \%$ & 28 & $100 \%$ & 28 & $100 \%$ \\
\hline
\end{tabular}

Students were asked to respond on statement whether they like the concept of representativeness assessment. It is found that $89 \%$ students really like the new insights of assessment-oriented. Some stated that the benefits of the assessment are mendapat nilai yang lebih maksimal, lebih banyak menambah point, kalau nggak bisa, bisa dibantu (translation: Getting higher scores, adding more points, if you can't, you can be helped). Only 11\% students responded negatively as can be seen in Table 5 above. The possible reason of the drawbacks which were written by students: Ada ketidaksamaan jawaban yang menyebabkan kekacauan, siswa yang membantu melupakan jawaban untuk membantu temannya (translation: There are different answers and opinion that can cause chaos, students forget the answers to help their friends).

The students were also asked whether the new insights are relevant to the nature of group work. The students' perception is revealed in Table 5. Ninety-three percent (93\%) students agreed with the relevance, while only two $(7 \%)$ students disagreed with the statement.

\section{CONCLUSION}

First, the study was designed to find out student's perception about language learning on cooperative group work enforcing ice breaker, model of group work, importance of group naming and role of group members. Table 6 bellow shows the summary for all items related to cooperative group work strategies. The overall data shows that high percentage of the respondents are in favor of group work.

The finding of this study was supported by the findings of other studies related to cooperative learning. The findings of Tamah (2011;2013), Nhu (2012) indicated positive perception from the students on cooperative learning. However, it does not support the finding of Campbell and Li (2006) and Bentley \& Warwick's (2013). Even though the result of this topic 
was inconsistent, the majority showed positive perception of the of cooperative learning was beneficial.

Table 6. Overall Perception on Cooperative Group Work Strategies

\begin{tabular}{|l|c|}
\hline \multicolumn{2}{|c|}{ Ice Breaker } \\
\hline Usefulness & $96 \%$ \\
\hline Necessity & $96 \%$ \\
\hline Influence & $89 \%$ \\
\hline Frequency & $61 \%$ \\
\hline \multicolumn{2}{|c|}{ Modelling } \\
\hline Usefulness & $89 \%$ \\
\hline Necessity & $96 \%$ \\
\hline Influence & $79 \%$ \\
\hline Frequency & $50 \%$ \\
\hline \multicolumn{2}{|c|}{ Group Naming } \\
\hline Usefulness & $86 \%$ \\
\hline Necessity & $86 \%$ \\
\hline Role of Group Members \\
\hline Usefulness & $86 \%$ \\
\hline Necessity & $79 \%$ \\
\hline
\end{tabular}

Second, this study was also designed to find out student's perception on representativeness assessment. Table 7 bellow shows the summary for all items related to representativeness assessment: usefulness, the necessity, students' preference, students' learning and the representation the nature of cooperative group work. The overall perception on representative assessment has a high percentage.

This finding is similar to the findings of Tamah \& Prijambodo (2014) and Tamah \& Wirjawan (2019). Based on students who were involved in the implementation of representative assessment, the application of that assessment was seen beneficial on students' perception and also on teachers' perception.

Table 7. Overall Perception on Representativeness Assessment

\begin{tabular}{|l|l|}
\hline Usefulness & $86 \%$ \\
\hline Necessity & $82 \%$ \\
\hline Preference & $89 \%$ \\
\hline Relevance with the nature of group work & $93 \%$ \\
\hline
\end{tabular}

To conclude, the result of the study showed that the respondents showed high percentage of perception on both cooperative group work strategies and representative assessment. 


\section{SUGGESTION}

There are some suggestions that the writer would like to give to English teachers, especially in implementing group work in the classroom. First, the students should be given modelling how to work in group. By doing so the students can get a picture of what they should do in the group. Second, the students should be given roles: chairperson, secretary, timekeeper and speaker. Giving role among group members might give students clear task to contribute. The possibility of hitchhiking will be minimized. Next, giving character name like caring, honest and enthusiastic could make the students indirectly behave nicely. The last suggestion is related with assessment. This study urges the balance between group learning and group assessment. When students learn together in group, they should also be assessed in group. The result of this study showed that the students had high level of agreement on group assessment, which is known as representative assessment. Therefore, English teachers should apply this representative assessment to assess group work.

The writer also hopes that there will be similar studies to give more enriching results about cooperative group work and representative assessment. To accomplish the hope, the writer would like to give three suggestions for future researchers. The first suggestion will be about the objective of the study. This study only focused on students' perception. The writer suggests that the future research also study students' achievement. Then the perception and achievement can be compared. The second suggestion will be about the respondents of the study. This study only used one class which was only twenty-eight students. It would be more convincing if future research uses bigger population. The last suggestion is related to the time management. The writer suggests that the future researcher conducts the study more than two months. The writer felt that she needed more time in applying all the strategies. Therefore, it would be better if the application of the strategies is prolonged so that students' perception result is more convincing. Another suggestion will be about the representative assessment. In this study, the writer only conducted assessment-oriented formative test once. The writer felt this kind of application might get better result if it is conducted more than once.

\section{REFERENCES}

Bentley, Y., \& Warwick, S. (2013). Students' experience \& perceptions of group assignments. The Higher Educational Academy, 17(2), 253-259.

Brown, H. D. (2001). Teaching by principles: An interactive approach to language pedagogy. New York: Pearson Education.

Campbell, J., \& Li, M. (2006). Asian students' perception of group work \& group assignments in a New Zealand tertiary institution. Edith Cowan University Research Online, 78-89.

Hodges, L. C. (2017). Ten research-based steps for effective group work. Idea Paper.

Holzman, L. (2009). Vygotsky at work and play. Oxford, UK: Routledge.

Lie, A. (2002). Cooperative learning: Mempratikkan Cooperative learning di ruang-ruang kelas. Jakarta: Grasindo. 
Nhu, N. L. (2012). Upper primary students' perceptions of small group learning in learning Vietnamese language. Master Education Thesis. Victoria University of Wellington.

Pramastiwi, P. (2014). High school learners' perception of their STAD learning experience in studying conditional sentences: Do gender and past achievement matter? Unpublished S-1 Thesis. English Department, Widya Mandala Catholic University Surabaya.

Santrock, J. W. (2009). Life-span development (Twelfth ed.). United States: McGraw-Hill Higher Education.

Sparks, S. D. (2017). Children must be taught to Collaborate, studies say. Retrieved February 28, 2018, from Education Week: https://www.edweek.org/ew/articles/2017/05/17/childrenmust-be-taught-to-collaborate-studies.html

Tamah, S. M. (2011). Student interaction in the implementation of the Jigsaw technique in language teaching. Published disertation. the Netherlands: Gronigen University.

Tamah, S. M. (2013). Teacher's enforcing positive interdependence. Magister Scientiae, 1, 74-84.

Tamah, S. M. (2014). Assessment in a Cooperative learning class. PASAA, 46, 199-213.

Tamah, S. M. (2015). Innovation in group work presentation: A challenge responded. Proceedings of the 24th MELTA International Conference, 380-393.

Tamah, S. M. (2015). Revitalizing formative test: A model of interactive test adminstration. The Proceedings of the 2nd National Conference on Language and Language Teaching, 139145.

Tamah, S. M. (2017). Pernak-pernik kerja kelompok berbasis pembelajaran Kooperative [translation: The nuts and bolts of Cooperative learning oriented group work]. Surabaya: Universitas Widya Mandala.

Tamah, S. M. \& Prijambodo, L. (2014). Metode asesmen berbasis pembelajaran Kooperatif [translation: Cooperative learning-based assessment. A research report. Retrieved from http://repository.wima.ac.id/4496/

Tamah, S. M., \& Prijambodo, V. L. (2015). Model asesmen pembelajaran Kooperatif: Strategi menjawab tantangan [translation: Models of Cooperative learning assessment: Strategies to respond to challenges]. Surabaya: Revka Petra Media.

Tamah, S.M. \& Wirjawan, J. V. D. (2019). Assessment-oriented formative test. The International Journal of Innovation and Learning, Vol.26, No.1, pp.66- 81 
44 | DOI: 10.33479/klausa.v4i01 